\title{
РОЛЬ НАВЧАЛЬНИХ ДИСЦИПЛІН У ФОРМУВАННІ САМОРЕФЛЕКСІЇ МАЙБУТНІХ ПЕДАГОГІВ
}

\begin{abstract}
Статтю присвячено висвітленню проблеми практичної підготовки майбутнього вчителя, зокрема виявленню таких вагомих чинників, як рефлексія, саморефлексія, що впливають на формування особистості майбутнього педагога. Проаналізовано методику виховання саморефлексії у процесі вивчення навчальних дисциплін.

Ключові слова: рефлексія, саморефлексія, професійна підготовка, майбутній педагог.
\end{abstract}

Статья посвящена проблемам практической подготовки будущего учителя, в часности, выявлению таких важных факторов, как рефлексия, саморефлексия, влияющих на формирование личности будущего педагога. Проанализирована методика воспитания саморефлексии в прочессе изучения учебных дисциплин.

Ключевые слова: рефлексия, саморефлексия, профессиональная подготовка, будущий педагог.

The article deals with the problem of practical training of the future teacher, particularly such factors as reflection, selfreflection which influence the future teacher individuality forming. Methodology of self-reflection education in the process of specialized subjects studying is analyzed.

Key words: reflection, self-reflection, professional training, the future teacher.

Уміння самостійно й творчо працювати - один із головних критеріїв, які характеризують готовність фахівця до професійної діяльності. Ефективним напрямком вдосконалення професійної підготовки студентів вишу є керований вплив на формування рефлексивних якостей у майбутнього вчителя.

Проблема формування саморефлексії є предметом досліджень багатьох сучасних зарубіжних та вітчизняних учених. Певні іiі аспекти розглянуто в працях М. Боришевськго, Л. Виготського, О. Главацької, І. Зязюна, А. Мудрик, С. Карпенчук та інші. Однак обгрунтування й аналіз психологопедагогічних технологій формування саморефлексії у майбутніх педагогів потребують детального вивчення.

Mета статmі: розкрити специфіку формування саморефлексії майбутніх педагогів у процесі вивчення навчальних курсів «Вступ до спеціальності», «Педагогіка», «Основи педагогічної майстерності».

Саморефлексія - одна 3 важливих професійно-педагогічних характеристик учителів, тому такі іiі компоненти, як самопізнання, самоаналіз, самооцінка і самоконтроль, доцільно досліджувати саме в умовах підготовки студентів до майбутньої педагогічної діяльності.

Формування саморефлексії здійснювалося шляхом залучення студентів до рефлексивної діяльності впродовж чотирьох років їх навчання у Кременецькому обласному гуманітарнопедагогічному інституті ім. Тараса Шевченка. В основу застосування відповідних методик була покладена ідея виховання рефлексивних якостей, починаючи від простих і завершуючи більш складними, яка належить Т. Колишевій й А. Мудрик [5; 6]. Структура виховного процесу включає два аспекти: теоретичний (I-II етапи) та практичний (III-IV етапи).

I-й етап - стимулювально-мотиваційний. Залучення студентів до рефлексивної діяльності та виховання у них рефлексивних якостей за допомогою навчального курсу «Вступ до спеціальності» (I курс, 72 годин).

II eman - навчально-діяльнісний. Використання навчальних курсів «Педагогіка» (I, II курси, 216 годин), «Основи педагогічної майстерності» (III курс, 54 годин) для виховання у студентів рефлексивних якостей.

III eman - процесуально-творчий. Удосконалення творчих навичок саморефлексії під час педагогічної практики та у процесі тренінгу.

IV eman - корекційно-регулятивний. Корекція сформованих компонентів саморефлексії завдяки вивченню спецкурсу «Саморефлексія у становленні педагогічної майстерності».

Проаналізуємо зміст та методику перших двох етапів, спрямовану на виховання саморефлексії у майбутніх педагогів.

Основні завдання стимулювально-мотиваиійного етапy (I курс) - викликати у студентів бажання оволодіти саморефлексією, сформувати мотиваційну сферу, актуалізувати в них рефлексивні знання, ознайомити з теоретичними основами, ідеями суб'єктної педагогіки та психології, виявити проблеми особистісної готовності до майбутньої професії. При цьому особливої ваги набуває удосконалення навчально-виховного процесу, орієнтованого на розвиток мотивації саморефлексії.

Варто наголосити на важливості цього початкового етапу формування саморефлексії у студентів, що здійснювалося у процесі вивчення навчальної дисципліни «Вступ до спеціальності», яка вводила першокурсників у світ рефлексії та сприяла усвідомленню ними значущості рефлексивних компонентів для майбутньої професійної педагогічної діяльності. Зміст зазначеної дисципліни $\epsilon$ специфічним. Ї̈ засвоєння стимулює студентів до самопізнання, глибшого осмислення своїх 
професійних намірів, самодіагностики нахилів до педагогічної діяльності.

Завдання курсу «Вступ до спеціальності» - ознайомити студентів із сутністю педагогічної діяльності, вимогами суспільства до перспектив іiі розвитку й удосконалення; визначити місце, роль у ній учителя та орієнтири у формуванні творчої особистості майбутнього педагога. Ця дисципліна допомагає першокурсникам оволодіти уміннями й навичками, необхідними для діагностики педагогічних здібностей, а також аналізу власної діяльності 3 метою подальшої успішної самореалізації в майбутній професії.

Форми й методи викладання курсу «Вступ до спеціальності» передбачають виокремлення значної кількості годин на самостійну роботу студентів (тести, діагностування нахилів, особистісних рис, складання програм самовиховання), спрямованої на самопізнання. Як засвідчило наше дослідження, саме за допомогою названої навчальної дисципліни нам вдалося залучити студентів до активної рефлексивної діяльності, зокрема до самопізнання та самоаналізу. Для цього було розроблено авторську робочу програму, що враховувала специфіку навчально-виховного процесу, вікові та індивідуальні особливості першокурсників, об'єктивну складність досліджуваного феномену, методичне забезпечення, особливості форм організації навчання та виховання.

Розкриємо можливості цієї робочої програми щодо формування рефлексивних компонентів. Так, засвоюючи теми першого («Сучасна система підготовки педагога») та другого («Педагогічна професія та особистість педагога») модулів згаданої дисципліни, першокурсники ознайомлювалися 3 принципами та основними формами організації навчального процесу у вищих педагогічних навчальних закладах, видами контролю, вимогами до оцінювання знань, умінь та навичок, особливостями організації самостійної роботи, методикою опрацювання навчальної літератури. При цьому важливим моментом $\epsilon$ зосередження уваги студентів на питаннях професійного самовиховання, на виробленні в першокурсників умінь і навичок, необхідних для діагностування власних педагогічних здібностей та аналізу навчальної діяльності. Вивчення кожної навчальної теми завершувалося тестовим діагностуванням рівня сформованості у студентів базових рефлексивних компонентів.

Особливої ваги ми надавали варіативній частині курсу, у якій було передбачено ознайомлення 3 роботою загальноосвітніх шкіл I-III ступенів, дошкільних навчальних закладів, що давало змогу студентам порівнювати свій рівень готовності до професійної діяльності 3 педагогічною майстерністю педагогів-практиків. Зустрічі з досвідченими педагогами та новаторами посилювали стимулюючий вплив, що яскраво виявився у творах-роздумах, які після відвідування освітніх закладів написали першокурсники. У цих творчих роботах студенти зазначили, що хочуть стати такими, як педагоги, з якими вони познайомилися.

Отже, навчальний курс «Вступ до спеціальності» 3 першої теми ефективно сприяв залученню студентів до рефлексивної діяльності. Вони обговорювали відповідні теми, як-от: особистість, ііі вихованість, педагогічна майстерність, сучасні педагогічні технології, інновації, проблеми сучасної освіти, самоосвіта, самовиховання.

Структура роботи, спрямованої на реалізацію виховних можливостей навчального курсу «Вступ до спеціальності», містить такі компоненти: 1) визначення мети і завдань: обгрунтування важливості рефлексивного компоненту кожної теми, розкриття їх виховного потенціалу; 2) організація навчального процесу відповідно до навчально-виховних завдань та змісту: використання карток самостійної роботи, опрацювання студентами науково-педагогічної літератури, спеціальних словників тощо; 3) навчальна діагностика: тестові завдання, самоаналіз, контрольні зрізи, бесіди, анкетування, спостереження; 4) підсумкове оцінювання: тестовий контроль, аналіз карток самостійної роботи.

Компонент 1. Визначення мети та зумовлених нею завдань було зорієнтоване на розкриття виховного потенціалу змісту вказаної навчальної дисципліни, яка здатна сформувати у першокурсників емоційно-особистісне ставлення до певних педагогічних явищ, готовність до педагогічної діяльності, поглибити зацікавленість обраною професією, сприяти засвоєнню студентами тих ціннісних орієнтацій, які забезпечують встановлення належних професійних відносин. При цьому ми керувалися теоретичними положеннями В. Сластьоніна, який наголошував, що визначення конкретизованих цілей, спрямованих на формування рефлексивних якостей, дає можливість переосмислити свій минулий досвід, виявити нове ставлення до проблеми [8, с. 84 - 92].

Компонент 2. Організація навчального процесу. Зазначена частина навчально-виховного процесу охоплювала такі заняття, які стимулювали саморозкриття, самовираження, самокорекцію знань та поведінки студентів. Першокурсники активно сприймали та осмислювали відповідний матеріал завдяки опрацюванню педагогічної літератури, педагогічних словників, застосуванню карток самостійної роботи.

Компонент 3. Навчальна діагностика. Цей складник виконував подвійну функцію: 3 одного боку, він сприяв вихованню саморефлексії у студентів, а з іншого - забезпечував встановлення рівня іії сформованості. Із метою діагностики ми використовували такі методи: тестові завдання, самоаналіз, контрольні зрізи, бесіди, анкетування, спостереження, розв'язування проблемно-ситуативних завдань, моделювання педагогічних ситуацій, виконання навчально-діагностичних та тренувальних 
вправ, творчі самозвіти, складання доповідей, проектування та аналіз наукових виступів.

Компонент 4. Підсумкове оцінювання. Воно здійснювалося за допомогою карток самостійного контролю та тестових завдань, які першокурсники виконували після кожного заняття.

Компоненти саморефлексії, сформовані у процесі вивчення курсу «Вступ до спеціальності», слугували основою для подальшого їх розвитку на наступних етапах дослідження.

II eman: навчально-діяльнісний (1-2 курс). Основні завдання цього етапу полягали в тому, щоб усебічно сприяти процесові виховання у студентів саморефлексії, відповідальності, ініціативності та нагромадженню досвіду рефлексивної діяльності, збагаченню їх необхідними рефлексивними знаннями, становленню майбутніх учителів як суб'єктів педагогічної діяльності, здатних усвідомлювати перспективу свого професійного розвитку. На зазначеному етапі головним змістом якого $\epsilon$ вивчення курсу «Педагогіка», реалізовано поетапне формування саморефлексії через творчі форми роботи.

Вивчення згаданої дисципліни надає змогу студентам грунтовно оволодіти теорією виховання учнів, що у майбутній практичній педагогічній діяльності є необхідною умовою та підгрунтям для досягнення вершин педагогічної майстерності.

Програму з навчального курсу ми структурували відповідно до рефлексивного змісту задля того, щоб актуалізувати психолого-педагогічну підготовку вчителя як складник його професійної компетентності та реалізувати іiі, зважаючи на вимоги кредитно-модульної системи організації навчального процесу у вишах. Програма містить такі розділи: «Загальні основи педагогіки», «Теорія виховання», «Теорія навчання», «Школознавство». Зміст програми, структурований на певні модулі, охоплює як традиційні аспекти навчальної дисципліни, так і проблеми, зумовлені нинішніми реаліями.

У розділі «Загальні основи педагогіки» репрезентовано відомості про педагогіку як науку, мету та ідеал виховання, про систему освіти в Україні (змістовий модуль «Теоретичні основи педагогіки»). Також подано матеріал про формування особистості (поняття про розвиток школярів, його вікову періодизацію, про виховання учнів (змістовий модуль «Формування особистості школяра»). Розгляд зазначеної проблематики рекомендовано здійснювати крізь призму формування рефлексивних знань.

Розділ «Теорія виховання» охоплює три змістові модулі: «Теоретичні основи процесу виховання» (сутність виховного процесу, його закономірності, принципи та методи); «Зміст виховання у національній школі» (основні напрямки виховання особистості - розумове, моральне, трудове, фізичне, естетичне); «Форми організації виховної роботи» (позакласна і позашкільна виховна робота; особистість і колектив; спільна виховна робота школи, сім’ї та громадськості; педагогічні основи виховної діяльності громадських організацій дітей, підлітків і дорослих). Увага студентів приверталася до необхідності здійснення саморефлексії під час сприйняття навчального матеріалу та важливості застосування набутих знань на практиці.

Розділ «Теорія освіти і навчання (дидактика)» передбачає ознайомлення майбутніх педагогів із теоретичними основами дидактики, ії предметом, завданнями, змістом освіти, сутністю навчального процесу та його закономірностями й принципами (змістовий модуль «Теоретичні засади навчання»), а також із формами організації й методами навчання, відповідним контролем та оцінюванням навчальних досягнень школярів (модуль «Змістовий компонент процесу навчання»). Вивчення цього розділу забезпечує набуття рефлексивних знань, умінь та навичок на основі засвоєння дидактичних технологій та вироблення творчого підходу до їх застосування, завдяки чому в студентів формуються якості саморефлексії.

У розділі «Школознавство» подано відомості про основи управлінської діяльності закладів освіти, особливості організації внутрішньошкільного управління (змістовий модуль «Основи школознавства»). Тут розкриваються завдання, зміст і форми методичної роботи в школі, поняття про інноваційну діяльність та передовий педагогічний досвід (змістовий модуль «Методична робота в школі. Інновації в освіті»). Цей розділ сприяє формуванню в майбутніх педагогів якостей, важливих для саморефлексії, пов'язаної з успішним здійсненням інноваційної діяльності та керівництвом закладами освіти, а також із встановленням гуманних взаємин між усіма учасниками освітнього процесу.

При вивченні курсу «Педагогіка» основну увагу було зосереджено на подальшому розвитку в майбутніх педагогів таких рефлексивних складників, як самооцінка, самопізнання, самоаналіз, самоконтроль. В основу відповідної технології покладено інтерактивні підходи, зорієнтовані на стимулювання, активізацію саморефлексії у студентів. Застосована методика передбачала виокремлення кількох основних компонентів.

Компонент 1. Визначення мети та завдань (вивчення рефлексивного компоненту змісту теорії навчання і виховання школярів, застосування набутих знань у педагогічній діяльності).

Компонент 2. Організація навчального процесу. Цей компонент охоплює: а) лекційний виклад матеріалу; б) поглиблення, закріплення знань на семінарських заняттях (застосування спеціальних запитань для міркувань, робота в творчих групах, проведення дискусій, підготовка студентами наукових повідомлень, розв'язування ними проблемно-ситуативних завдань). 
Компонент 3. Навчальна діагностика: самодіагностика, саморегуляція рівня вихованості, самооцінка.

Компонент 4. Підсумкове оцінювання: тестовий контроль, аналіз карток самостійної роботи.

Особливого значення набувало засвоєння навчального матеріалу з розділу «Теорія виховання». Вивчення тем «Мета виховання», «Суть процесу виховання» стали поштовхом до серйозної аналітичної роботи над собою. Студенти визначали мету й конкретні завдання, які ставили перед собою упродовж дня, тижня, і спостерігали, якою мірою заплановане було реалізованим. Після вивчення тем «Принципи виховання», «Методи та прийоми виховання» зроблено реальний крок, спрямований на поглиблення саморефлексії. Так, побувавши в школі, студенти запропонували обговорити відвідані уроки, виховні заходи, щоб порівняти своє розуміння певних загальних положень із втіленням їх на практиці. Учасники обговорення також намагалися з'ясувати, чи є у них власні принципи, що виявляються у ставленні до людей, поведінці й навчанні. Крім того, лабораторне заняття на тему «Методи та прийоми виховання» мало на меті виробити уміння оцінювати ефективність застосування методів і прийомів виховання 3 позицій саморефлексії. Після загальноприйнятої частини, що включала обговорення теоретичних питань (поняття про метод, прийом, засіб виховання; різні наукові підходи до класифікації методів виховання, їхня характеристика та вимоги до вибору цих методів), відбулася демонстрація моделей педагогічної самопрезентації вчителя.

На цьому занятті студенти демонстрували підготовлені стратегії самопрезентації (продуктивні, непродуктивні, маніпулятивні, негативні). Разом із викладачем було визначено умови ефективного застосування методів впливу на підсвідомість вихованців.

Зацікавлення у студентів і їхню активну участь викликав аналіз диспутів у ситуації: «А як уважаєте Ви?». Він передбачав визначення дискусійних тем для певної вікової категорії, обгрунтування й формулювання проблемних запитань та демонстрування фрагментів відповідного диспуту. Так, наприклад, під час етичної бесіди «Друг - це «інший я», рекомендованої для проведення у 8 класі, було запропоновано запитання: Чи можна дружити з людиною, яка менше розвинена та цікава, ніж Ви? Чи збагачує людей дружба? Як Ви вважаєте, чи можуть дружити люди 3 подібними характерами? А з протилежними? Як Ви розумієте слова «безкорислива дружба»? А чи може бути «корислива дружба»? Студенти відповідали також на запитання «для себе» : «А який друг я?», «Чи справді я маю друга?», «Чому саме цю людину я обрав другом?». Зауважимо, що цей прийом активізації саморефлексивної діяльності ми застосовували на кожному практичному занятті.

Вивчаючи розділ «Теорія виховання», студенти оцінювали не лише змістову сторону різних завдань, але й рівень саморефлексії у позиції «Я - класний керівник», «Я - людина». Ефективним методом виявився аналіз вибірок із наукових статей та педагогічної періодики 3 теми «Проблема застосування методів виховання за умови гуманізації школи». Інтерес до гуманістичного ідеалу як виховної проблеми посилювався, якщо студент на матеріалі оцінювання чиєїсь педагогічної позиції набував уміння аналізувати самого себе. Використовувався ще й інший метод - вибір у дії. Викладач ставив на дошці крапку з написом «Я», від якої відводив лінії (за кількістю студентів у групі). Кожен студент підходив до дошки і на кінці однієї з вільних ліній писав ім'я одногрупника, якого він обрав би своїм учителем. Згодом студенти по черзі обгрунтовували свій вибір. Тим, хто з педагогічного погляду не виявив себе (кого не вибрали), було запропоновано зробити самоаналіз: «Яким треба стати, щоб товариші в мені побачили педагога?».

Розвиток у майбутнього вчителя рефлексивних якостей, умінь та навичок є важливим складником його професійної підготовки, про що свідчать результати проведеного нами дослідження. Наголошуємо на важливості початкового етапу формування саморефлексії у студентів, що здійснювалося в процесі вивчення навчальної дисципліни «Вступ до спеціальності», яка вводила першокурсників у світ рефлексії та сприяла усвідомленню ними значущості рефлексивних компонентів для майбутньої професійної педагогічної діяльності. 3'ясувано, що зміст зазначеної дисципліни є специфічним, іiі засвоєння стимулює студентів до самопізнання, глибшого осмислення своїх професійних намірів, самодіагностики нахилів до педагогічної діяльності.

Перспективу подальших досліджень убачаємо в розробленні ефективної технології удосконалення творчих навичок саморефлексії у процесі тренінгу та педагогічної практики, а також здійсненні корекції сформованих компонентів саморефлексії, взявши за основу вивчення спецкурсу «Саморефлексія у становленні педагогічної майстерності».

\section{Література}

1. Боришевський М. Й. Моральна саморегуляція поведінки особистості: понятійний апарат / М. Й. Боришевський. - К. : ІПАПН України, 1993. - 23 с. 2. Выготский Л. С. Собрание починений: в 6 т. / Лев Семенович Выготский; гл. ред. А. В. Запорожец. - М. : Педагогика, 1983. - Т. 3 : История развития высших психических функций. - 1984. - 369 с. 3. Главацька О. Л. Основи самовиховання особистості : [навч.-метод. посібн.] / О. Л. Главацька. - Тернопіль : Кондор, 2008. - 206 с. 4. Карпенчук С. Г. Теорія і методика виховання : [навч. посібн. для студ. вищ. навч. закл.] / С. Г. Карпенчук. - К. : Вища школа, 2005. - 343 с. 5. Колышева Т. А. Подготовка учителя музыки к профессионально-личностной рефлексии в системе высшего педагогического образования: автореф. дис. на соискание науч. степени канд. пед. наук: спец. 13.00.02 «Теория и методика обучения и воспитания» / Т. А. Колышева. - М., 1997. - 51 с. 6. Мудрик А. В. Учитель: мастерство и 
вдохновение / Анатолий Викторович Мудрик. - М. : Просвещение, 1981. - 159 с. 7. Педагогічна майстерність / за ред. І. А. Зязюна. - К. : Вища школа. - 349 с. 8. Сластёнин В. А. Педагогика: инновационная деятельность / В. А. Сластёнин, Л. С. Подымова. - М. : ИЧП «Изд-во Магистр», 1997. - 224 с. 